\title{
Citrus sinensis (L) Peels Extract Inhibits Metastasis of Breast Cancer Cells by Targeting the Downregulation Matrix Metalloproteinases-9
}

\author{
Meiny Suzery ${ }^{1 *}$, Bambang Cahyono ${ }^{1}$, Nur Dina Amalina ${ }^{2}$ \\ ${ }^{1}$ Department of Chemistry, Faculty of Sciences and Mathematics, Diponegoro University, Semarang, Indonesia; ${ }^{2}$ Pharmacy \\ Study Program, Faculty of Mathematics and Natural Sciences, Semarang State University, Semarang, Indonesia
}

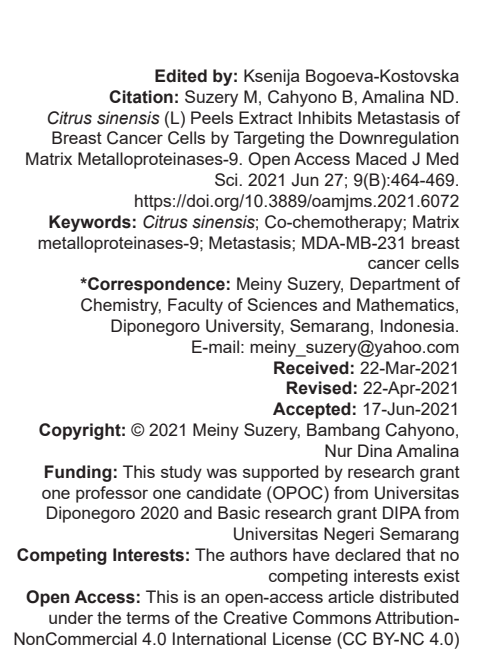

\section{Introduction}

Breast cancer $(B C)$ is the most frequent cancer among women, with 3.8 million death case in 2019 [1]. The most cases of BC death are mainly due to metastasis of primary cancer to various organ sites. It is a multi-faceted mechanism that results from orchestrated activities, including adhesion, invasion, and migration [2]. Extracellular matrix degradation (ECM) by proteolytic enzymes and subsequent cancer invasion is important early stages of metastasis [3]. Matrix metalloproteinases (MMPs) is the most crucial proteolytic enzyme that degrades the ECM. Accordingly, the MMP-9 expression is associated with $\mathrm{BC}$ metastatic and invasion [4], [5]. Therefore, it is necessary to develop new strategy that has the potential to inhibit metastatic BC cells.

Recently, the main treatment for BC metastatic is chemotherapy [6]. However, this therapy is not effective and often leads to side effect such as metastatic and relapse [7]. The previous study reported that doxorubicin (DOX) induces lamellipodia, this formation is the initial stage of metastatic [8], [9]. Thus, studies toward finding efficient therapeutic strategies with minimum side effects are critical for expansion of existing treatment options for BC. Natural herbal medicine is rich sources of bioactive molecules and being developed to compensate for the drawbacks and toxicity of chemotherapy. Flavonoid from Citrus sinensis proven to have an anticancer activity with multiple target side on several type of cancer. Hesperetin, a secondary metabolite of $C$. sinensis inhibited Rac-1 expression, the expression of a gene that regulated metastatic [10]. Hesperidin is also shown to be inhibited MCF-7 cancer cell grow [11]. However, the mechanism of $C$. sinensis for inhibiting DOX-induced metastasis is remain unclear. In this study, we investigated the effect of C. sinensis peels extract (CSP) in combination with DOX on BC metastatic MDA-MB-231 proliferation and its molecular mechanisms of action through in silico approach. 


\section{Materials and Methods}

\section{Plant material}

C. sinensis (Rutaceae) peels were collected from Bandungan, Semarang - Central Java, Indonesia. The identity of the plant was confirmed by biologist at Biology Department, Diponegoro University.

\section{Preparation of plant extract}

The peels of $C$. sinensis was collected, chopped into small pieces and dried under shade. The dried peels $(250 \mathrm{~g}$ ) were re-macerated using ethanol $96 \%$ for 3 days at room temperature based on [12] with slight modification. The extracts were evaporated in the under reduce pressure in a rotary vacuum evaporator at $50^{\circ} \mathrm{C}$ to result the crude extracts. The crude extracts were dried in a vacuum freeze dryer and preserved at $-20^{\circ} \mathrm{C}$ for subsequent analysis.

\section{Cell culture}

MDAMB-231 (ECACC \#92020424) were cultured in DMEM medium (Gibco, San Francisco, CA, USA) supplemented with $10 \%$ fetal bovine serum (Gibco, USA), $12.5 \mu \mathrm{g} / \mathrm{ml}$ Amphotericin B (Gibco, USA), $150 \mu \mathrm{g} / \mathrm{ml}$ Streptomycin, and $150 \mathrm{IU} / \mathrm{ml}$ Penicillin (Gibco, USA). The cell culture was cultivated at $37^{\circ} \mathrm{C}$ under $5 \%$ CO2. Culture media were renewed every $2-3$ days, and cells were subculture when confluent of $80-90 \%$. For assays, only cells with $>90 \%$ viability, passage number $<10$, and in the log growth phase were used.

\section{Cell viability assay}

The cell viability was based on a 3-(4,5-dimethyl-2-thiazolyl)-2,5-diphenyl-2 Htetrazolium bromide (MTT) assay according to Mosmann [13], Suzery et al. [14] with slight modification. MDA-MB-231 $5 \times 10^{3}$ cells/well was seeded in 96 well-plate and incubated at $37^{\circ} \mathrm{C}$ under $5 \% \mathrm{CO} 2$ for $24 \mathrm{~h}$. Cells were treated in several concentration of CSP $(10-500 \mu \mathrm{g} / \mathrm{ml})$, DOX (1-500 nM) or CSP/ DOX combination exposed for $24 \mathrm{~h}$. Untreated cells were regarded as negative controls. After treatment, cells were treated with $0.5 \mathrm{mg} / \mathrm{mL}$ of MTT (Biovision) and incubated further for $4 \mathrm{~h}$. Then, DMSO $100 \mu \mathrm{l}$ was added to dissolve the crystal of formazan. The absorbance was measured by ELISA reader (Biorad iMarkTM Microplate Reader) at $\lambda 595 \mathrm{~nm}$ [14].

\section{Combination index (Cl)}

The combined effect of CSP and DOX was evaluated using $\mathrm{Cl}$ and isobologram were analyzed with CompuSyn $®$ software based on the Chou-Talalay method as describe previously [15]. The combination effect is defined as: $\mathrm{Cl}<1$ is a synergistic effect, $\mathrm{Cl}=1$ is an additive effect, and $\mathrm{Cl}>1$ is an antagonistic effect.

\section{Molecular docking}

The protein-Ligand Ant System program was used for simulation of molecular docking. The structure of protein MMP-9 (PDB ID: 2OVX) has been download from www.rcsb.org The YASARA software was used to prepared the protein before docking simulation (www. yasara.org/viewdl.htm), on the other hand, the ligand was prepared using ChemAxon (www.chemaxon. com/marvin/download-user.html). Furthermore, the visualization of docking simulation in this study was determined under PyMol www.pymol.org.

\section{Statistical analysis}

Data are presented as the means \pm standard deviation. All calculations were carried out using IBM SPSS 22.0 (IBM Corp., Armonk, NY, USA). The statistical significance of the differences group's differences was assessed using one-way ANOVA and continued with Fisher's least significant difference post hoc. $\mathrm{p}<0.05$ was considered significant.

\section{Results}

\section{The effect of CSP and DOX on} MDA-MB-231 cell viability

A single treatment of CSP and DOX individually possessed strong cytotoxic effect with dose-dependent manner. After $24 \mathrm{~h}$ treatment, the $\mathrm{IC}_{50}$ value of CSP and DOX in MDA-MD-231 was $344 \mu \mathrm{g} / \mathrm{mL}$ and $85 \mathrm{nM}$, respectively (Figure 1). Interestingly, low doses of DOX changed cell morphology, which is characterized by elongation of lamellipodia (Figure 2).

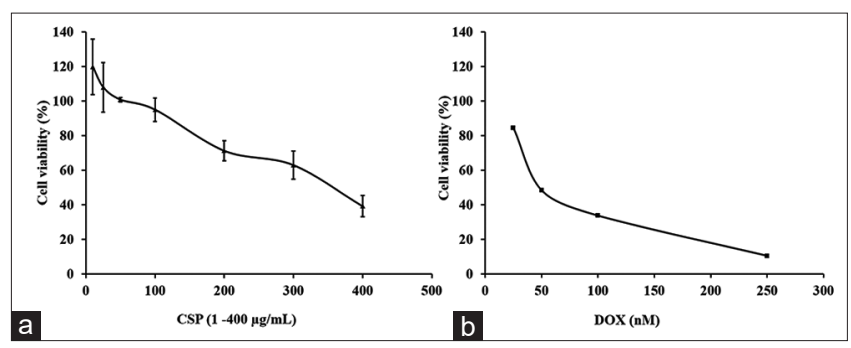

Figure 1. : Cytotoxic activity of Citrus sinensis peels extract (CSP) and doxorubicin (DOX)on MDA-MB-231 cells. Cells $5 \times \times 10^{3}$ were seeded for $24 h$ in 96 -well plate, then treatedwith (a) CSP and (b) DOX individually and incubated for $24 \mathrm{~h}$. cell viability profile expressed mean $\pm S E$ of 3 experiments. $I C_{50}$ obtained from a linear regression calculation of log concentration versus cell viability with $p \& / t ; 0.05$.

In this study, CSP has been explored as natural co-chemotherapeutic agent against highly 
metastatic BC cells. To explore the combination effect of CSP and DOX on cell viability, we used one-eighth, one-fourth, and half of $\mathrm{IC}_{50}$ value of CSP and DOX. The combination of $177 \mu \mathrm{g} / \mathrm{mL}$ of CSP and $42.5 \mathrm{nM}$ DOX decreased cell viability up to $5.11 \%$ (Figure $3 a$ ). Based on the cell viability on combination treatment, we calculated the $\mathrm{Cl}$ using Chou-Talay methods. A Cl plot showed that all off combination treatment exhibited a synergistic effect with $\mathrm{Cl}$ value $0.55-3.48$ (Figure $3 \mathrm{~b}-\mathrm{c}$ ). Seven plot indicated antagonistic effect and nine plot indicated synergistic effect. The highest synergistic effect was CSP one-sixteenth $\mathrm{IC}_{50}$ and DOX one-fourth
$\mathrm{IC}_{50}$. The isobologram showed that isobologram plot of CSP/DOX combination was positioned to the bottom left of the curve, which suggested that CSP had a synergistic effect with DOX.

\section{Molecular docking study of secondary metabolite of CSP on MMP-9}

The CSP contains various metabolite compound that possess cytotoxic activity on several cancer cells, such as hesperetin, hesperidin, naringenin,

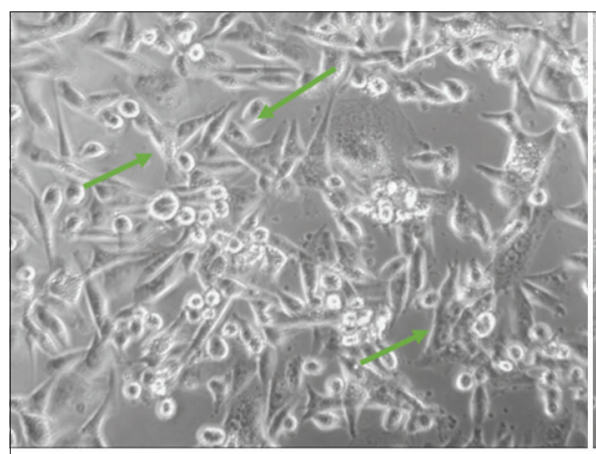

Untreated

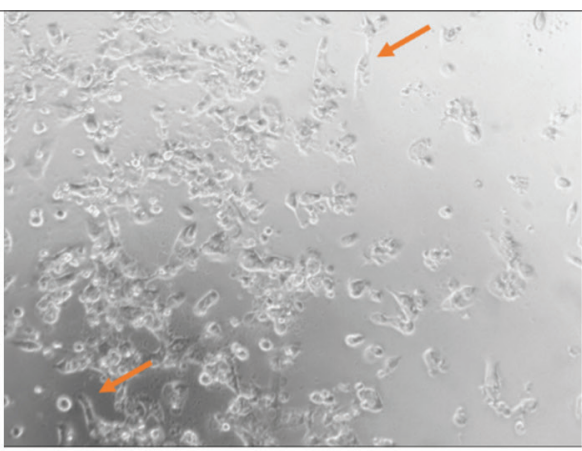

Doxorubicin

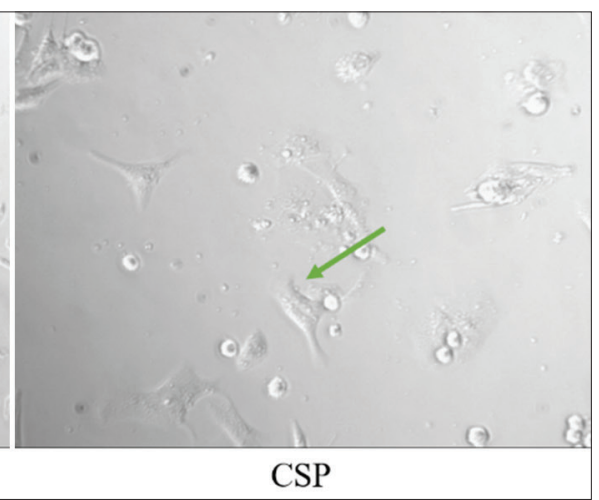

CSP

Figure 2: The effect of Citrus sinensis peels extract (CSP) and doxorubicin (DOX) on cell morphology. Visible morphological changes and population of cells in treatment of untreated, DOX $10 \mathrm{nM}$ and CSP $200 \mu \mathrm{g} / \mathrm{mL}$. Observations of Cell morphology performed using an inverted microscope with a magnification of 100x. Green arrow indicated live cells and red arrow indicated lamellipodia elongation and shrinker cells

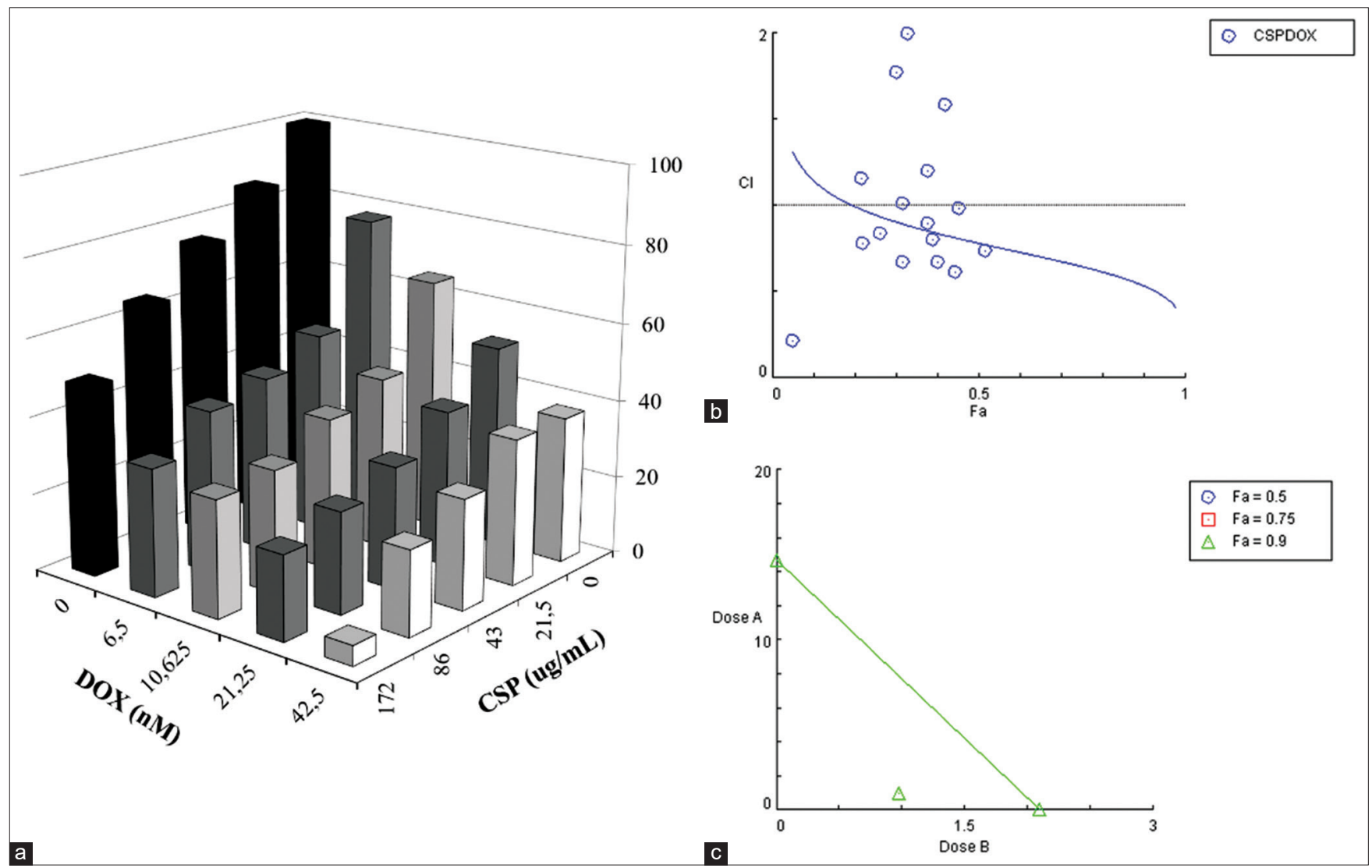

Figure 3: (a) Effect of Citrus sinensis peels extract (CSP) in combination with doxorubicin (DOX) on the MDA-MB-231 cell viability. (b) Combination index plot, and (c) isobologram for a combination of CSP and DOX calculated by CompuSyn software based on Chou-Talalay method 
nobiletin, and tangeretin [16], [17], [18], [19]. The evaluation of the binding activity showed that all off CSP secondary metabolite compound possessed a higher docking score than that DOX. On the other hand, according to the visualization study of CSP secondary metabolite compound performed different binding interaction compared with those of DOX and native ligand (Table 1 and Figure 4). Hesperetin has the higher binding interaction with MMP-9 protein. On the MMP-9, hesperetin interacted with the amino acid residues Tyr 423, Leu 418, Leu 188, Ala 189, GIn 402, and $\mathrm{His} 411$.

\section{Discussion}

The MTT assay was used to evaluate the cytotoxic effect to determine the potency of CSP to enhance the cytotoxicity of DOX on highly metastatic BC MDA-MB-231 cells. The aims of this study were to develop CSP as a co-chemotherapy agent to inhibited DOX-induced metastasis. The point of co-chemotherapy is to decrease the side effect and enhance the efficacy of drug [20]. CSP is a natural herbal medicine which

Table 1: Docking score of secondary metabolites CSP on MMP-9

\begin{tabular}{lll}
\hline Ligand & Binding interaction $(\mathrm{kcal} / \mathrm{mol})$ & RMSD $(\AA)$ \\
\hline Native ligand & -37.4444 & 0.3603 \\
DOX & -22.4682 & 1.9025 \\
Hesperidin & -23.9460 & 1.4127 \\
Hesperetin & -25.0878 & 1.3572 \\
Naringenin & -22.5614 & 1.4914 \\
Nobiletin & -24.0417 & 1.2355 \\
Tangeretin & -25.0748 & 1.7595 \\
\hline DOX: Doxorubicin, MMP-9: Matrix metalloproteinases-9.
\end{tabular}

proven to have a cytotoxic effect on several cancer cells. Hesperetin, a one of secondary metabolite of CSP show to enhance the effect of DOX against HER2+ BC cells [10]. Hesperidin is also enhanced the effectiveness of DOX and 5-FU through apoptosis induction [11], [21]. A single treatment of CSP and DOX individually possessed strong cytotoxic effect with dosedependent manner and the low dose of DOX induced lamellipodia elongation. This phenomenon supports the previous studies that DOX in concentration of $10 \mathrm{nM}$ induced lamellipodia formation through the activate transforming growth factor beta (TGF $\beta$ ) signaling pathway [9], [22]. The activation of TGF $\beta$ induces EMT caused inducing motility of cell and metastatic [8]. Further, the cytotoxic combination showed that that CSP had a synergistic effect with DOX with $\mathrm{Cl}$ value $<1$. These results suggested that CSP could sensitize highly metastatic BC MDA-MB-231 cells to DOX. Therefore, the further assay was need to be evaluated the molecular mechanism of CSP secondary metabolite compound on the MMP-9 interaction through molecular docking approach.

The CSP contains various metabolite compound that possess cytotoxic activity on several cancer cells, such as hesperetin, hesperidin, naringenin, nobiletin, and tangeretin [16], [17], [18], [19], [23]. A simulated interaction analysis of the CSP secondary metabolite compound was performed in the target sample using molecular docking simulation to validate the CSP molecular mechanism of the antimetastatic behavior hypothesis. The target protein for screening the antimetastatic effect was MMP-9. The MMP-9 protein, which played a role in ECM, was used as a target protein for antimetastatic activity screening [24]. Statistical

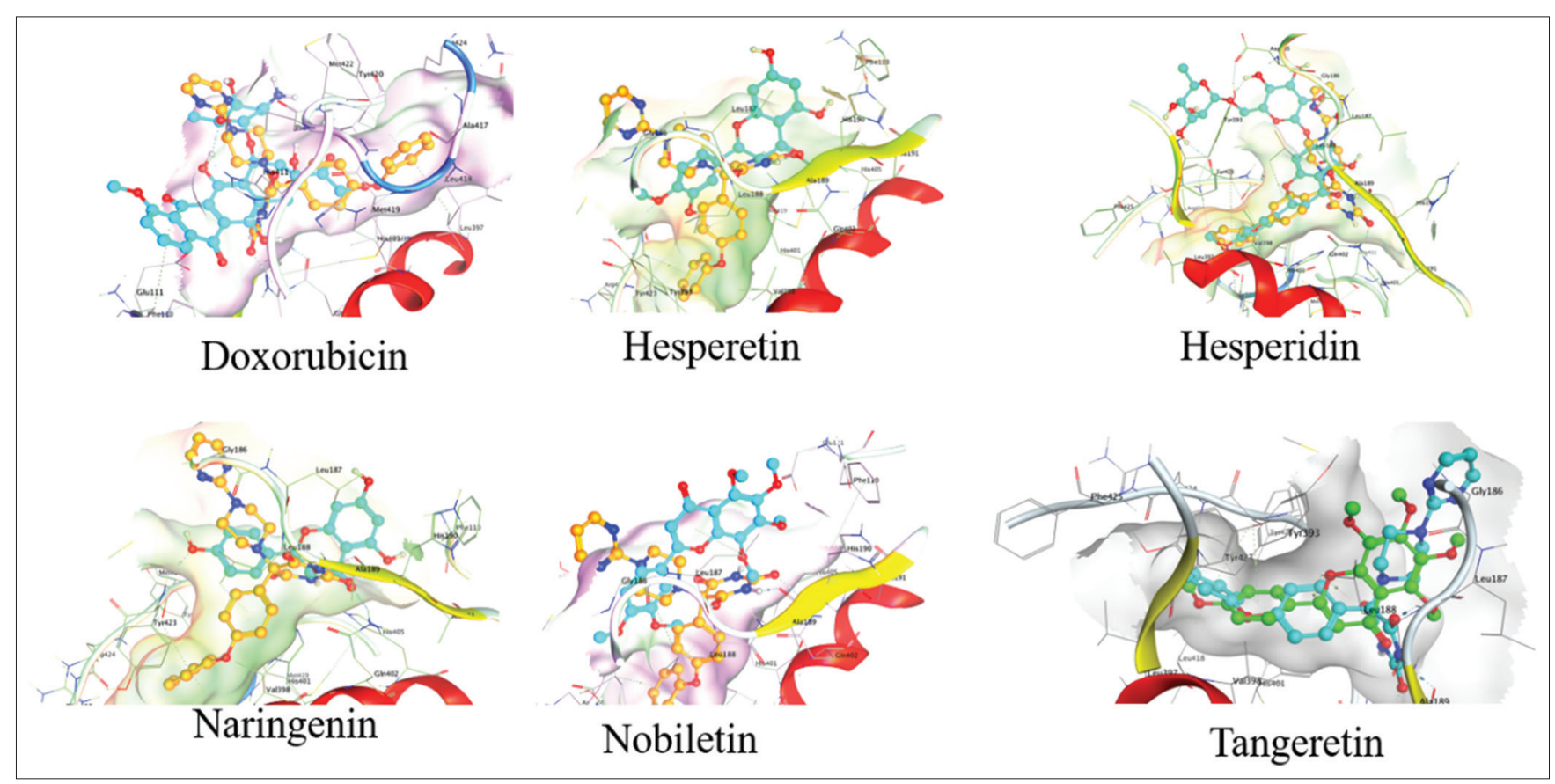

Figure 4: The visualization of compound interaction on matrix metalloproteinases-9. Molecular interaction was evaluated using PyMol. Compound is represented as gold/green balls and sticks, while the native ligand is represented as Tosca balls and sticks 
analysis showed that the molecular docking findings were valid based on the RMSD value of $<2 \AA$ (Table 1 ). The evaluation of the binding activity showed that all off CSP secondary metabolite compound possessed a higher docking score than that DOX. Overall, the CSP may have had possible interaction capabilities with MMP-9. Thus, CSP is a potential candidate that can be used as a natural co-chemotherapeutic agent based on its antimetastatic activity.

\section{Conclusion}

The combination of CSP and DOX enhanced sensitivity of MDA-MB-231 BC cells toward DOX. Furthermore, CSP metastasis cell through MMP-9 interaction. More importantly, our findings suggested that CSP potential to be developed as natural cancer therapeutic agent.

\section{References}

1. Sinaga ES, Ahmad RA, Shivalli S, Hutajulu SH. Age at diagnosis predicted survival outcome of female patients with breast cancer at a tertiary hospital in Yogyakarta, Indonesia. Pan Afr Med J. 2018;31:1-9. https://doi.org/10.11604/pamj.2018.31.163.17284 PMid:31086616

2. Mythreye K, Blobe GC. Proteoglycan signaling co-receptors: Roles in cell adhesion, migration and invasion. Cell Signal. 2009;21(11):1548-58. https://doi.org/10.1016/j. cellsig.2009.05.001

PMid:19427900

3. Walker C, Mojares E, Del Río Hernández A. Role of extracellular matrix in development and cancer progression. Int J Mol Sci. 2018;19(10):3028. https://doi.org/10.3390/ijms19103028 PMid:30287763

4. Jabłońska-Trypuć A, Matejczyk M, Rosochacki S. Matrix metalloproteinases (MMPs), the main extracellular matrix (ECM) enzymes in collagen degradation, as a target for anticancer drugs. J Enzyme Inhib Med Chem. 2016;31(1):177-83. https:// doi.org/10.3109/14756366.2016.1161620

PMid:27028474

5. Ikawati M, Jenie RI, Utomo RY, Amalina ND, Nur Ilmawati GP, Kawaichi M, et al. Genistein enhances cytotoxic and antimigratory activities of doxorubicin on $4 \mathrm{~T} 1$ breast cancer cells through cell cycle arrest and ROS generation. J Appl Pharm Sci. 2020;10(10):95-104. https://doi.org/10.7324/japs.2020.1010011

6. Ran S. The role of TLR4 in chemotherapy-driven metastasis. CancerRes. 2015;75(12):2405-10. https://doi.org/10.1158/00085472.can-14-3525

PMid:25998620

7. Griffiths CL, Olin JL. Triple negative breast cancer: A brief review of its characteristics and treatment options. J Pharm Pract. 2012;25(3):319-23. https://doi.org/10.1177/0897190012442062 PMid:22551559

8. Bandyopadhyay A, Wang L, Agyin J, Tang Y, Lin S, Yeh IT, et al.
Doxorubicin in combination with a small TGFbeta inhibitor: A potential novel therapy for metastatic breast cancer in mouse models. PLoS One. 2010;5(4):e10365. https://doi.org/10.1371/ journal.pone.0010365

PMid:20442777

9. Amalina N, Nurhayati IP, Meiyanto E. Doxorubicin induces lamellipodia formation and cell migration. Indones J Cancer Chemoprev. 2017;8(2):61. https://doi.org/10.14499/ indonesianjcanchemoprev8iss2pp61-67

10. Nurhayati IP, Khumaira A, Ilmawati GP, Meiyanto E, Hermawan A. Cytotoxic and antimetastatic activity of hesperetin and doxorubicin combination toward her2 expressing breast cancer cells. Asian Pac J Cancer Prev. 2020;21(5):1259-67. https://doi.org/10.31557/apjcp.2020.21.5.1259

PMid:32458631

11. Febriansah R, Putri DD, Sarmoko S, Nurulita NA, Meiyanto E, Nugroho AE. Hesperidin as a preventive resistance agent in MCF-7 breast cancer cells line resistance to doxorubicin. Asian Pac J Trop Biomed. 2014;4(3):228-33. https://doi.org/10.1016/ s2221-1691(14)60236-7

PMid:25182442

12. Tanvir EM, Hossen MS, Hossain MF, Afroz R, Gan SH, Khalil MI, et al. Antioxidant properties of popular turmeric (Curcuma longa) varieties from Bangladesh. J Food Qual. 2017;2017:8471785. https://doi.org/10.1155/2017/8471785

13. Mosmann T. Rapid colorimetric assay for cellular growth and survival: Application to proliferation and cytotoxicity assays. J Immunol Methods. 1983;65(1-2):55-63. https://doi. org/10.1016/0022-1759(83)90303-4 PMid:6606682

14. Suzery M, Cahyono B, Amalina ND. Antiproliferative and apoptosis effect of hyptolide from Hyptis pectinata (L.) poit on human breast cancer cells. 2020;10(2):1-6. https://doi. org/10.7324/japs.2020.102001

15. Khamis AA, Ali EM, El-Moneim MA, Abd-Alhaseeb MM, El-Magd MA, Salim El. Hesperidin, piperine and bee venom synergistically potentiatetheanticancer effectoftamoxifenagainst breast cancer cells. Biomed Pharmacother. 2018;105:1335-43. https://doi.org/10.1016/j.biopha.2018.06.105

PMid:30021371

16. Meiyanto E, Hermawan A, Anindyajati A. Natural productsfor cancer-targeted therapy: Citrus flavonoids as potentchemopreventive agents. Asian Pac J Cancer Prev.2012;13(2):427-36. https://doi.org/10.7314/apjcp.2012.13. 2.427PMid:22524801

PMid:22524801

17. Park HJ, Kim MJ, Ha E, Chung JH. Apoptotic effect of hesperidin through caspase 3 activation in human colon cancer cells, SNU-C4. Phytomedicine. 2008;15(1-2):147-51. https://doi. org/10.1016/j.phymed.2007.07.061

PMid: 17897817

18. Korga A, Ostrowska $M$, Jozefczyk A, Iwan M, Wojcik $R$, Zgorka G, et al. Apigenin and hesperidin augment the toxic effect of doxorubicin against HepG2 cells. BMC Pharmacol Toxicol. 2019;20(1):22. https://doi.org/10.1186/s40360-019-0301-2 PMid:31053173

19. Priscilla $\mathrm{DH}$, Jayakumar $\mathrm{M}$, Thirumurugan K. Flavanone naringenin:An effective antihyperglycemicand antihyperlipidemic nutraceutical agent on high fat diet fed streptozotocin induced Type 2 diabetic rats. J Funct Foods. 2015;14:363-73. https://doi. org/10.1016/j.jff.2015.02.005

20. Tun JO, Salvador-Reyes LA, Velarde MC, Saito $N$, Suwanborirux K, Concepcion GP. Synergistic cytotoxicity of renieramycin $\mathrm{M}$ and doxorubicin in MCF-7 breast cancer cells. Mar Drugs. 2019;17(9):536. https://doi.org/10.3390/ md17090536 
PMid:31527453

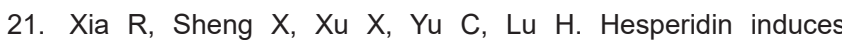
apoptosis and G0/G1 arrest in human non-small cell lung cancer A549 cells. Int J Mol Med. 2018;41(1):464-72. https:// doi.org/10.3892/ijmm.2017.3250

PMid:29138795

22. Jenie RI, Amalina ND, Ilmawati GP, Utomo RY, Ikawati M, Khumaira A, et al. Cell cycle modulation of $\mathrm{CHO}-\mathrm{K} 1$ cells under genistein treatment correlates with cells senescence, apoptosis and ROS level but in a dose-dependent manner. Adv Pharm
Bull. 2019;9(3):453-61. https://doi.org/10.15171/apb.2019.054

PMid:31592434

23. Amalina ND, Suzery M, Cahyono B. Mengungkap potens metabolit sekunder tanaman herbal Indonesia untuk menghentikan metastasis kanker payudara: Pendekatan in-silico. Indones J. 2020;9(3):154-9.

24. Ujfaludi Z, Tuzesi A, Majoros H, Rothler B, Pankotai T, Boros IM. Coordinated activation of a cluster of MMP genes in response to UVB radiation. Sci Rep. 2018;8(1):1-10. https://doi.org/10.1038/ s41598-018-20999-6 